\title{
Othematoma pada kucing Persia di Klinik Satwagia BPC
}

\author{
Ana Rufaidah Nasheer ${ }^{1, *}$, Reinilda Alwina ${ }^{2}$ \\ ${ }^{1}$ Program Pendidikan Profesi Dokter Hewan, Fakultas Kedokteran Hewan, Institut Pertanian Bogor \\ ${ }^{2}$ Dokter Hewan Praktisi Hewan Kecil di Klinik Satwagia BPC, Bogor
}

\begin{abstract}
ABSTRAK: Seekor kucing betina ras Persia yang berusia 3 tahun mengalami pembengkakan pada telinga kiri. Keadaan kedua telinga kotor dan ditemukan adanya discharge nasal bewarna putih keruh saat dilakukan pemeriksaan di Klinik Satwagia BPC. Pemeriksaan penunjang berupa pemeriksaan serumen telinga secara mikroskopis dan hematologi dilakukan sebelum keputusan pembedahan. Tindakan yang diambil adalah pembedahan telinga sebelah kiri dengan pengobatan pasca bedah yaitu injeksi asam traneksamat intravena, antibiotik amoxilin subkutan, tolfenamic acid intramuskular, mulitivitamin dan imunomodulator per oral. Setiap hari luka sayatan diolesi salep biogenta dan dilakukan pemasangan balut tekan pada telinga selama 2 minggu. Luka terlihat mulai mengering dan kucing sudah beraktivitas normal setelah 1 minggu pascabedah.
\end{abstract}

Kata kunci:

kucing, othematoma, bedah

\section{- PENDAHULUAN}

Aural hematoma (othematoma) merupakan pembengkakan telinga karena pembuluh darah daun telinga yang pecah diantara lapisan dalam kulit dan luar tulang rawan sehingga menyebabkan telinga terisi dengan cairan darah (Islami et al. 2018). Karena tulang rawan telinga mendapatkan pasokan darah secara langsung dari kulit yang terletak diatasnya, kejadian ini dapat mengurangi aliran darah yang menyebabkan bagian-bagian dari tulang rawan mengerut sampai akhirnya mati. Hal ini mengakibatkan kebengkakkan dan perubahan bentuk dari telinga (Henderson \& Horne 2003).

Othematoma sering terjadi pada anjing dan kucing di semua umur (Macphail 2016). Frekuensi kejadian lebih sering pada anjing dibandingkan kucing (Hewitt \& Bajwa 2020). Faktor predisposisi othematoma yakni hewan bertelinga panjang dan terkulai, trauma benturan, infeksi telinga, dan reaksi hipersensitifitas yang menyebabkan gatal sehingga hewan menggaruk dan menggelengkan kepalanya secara berlebihan (Harvey et al. 2005).

Pengobatan untuk menangani kasus othematoma yaitu auriculocentesis, auricular incision, dan pembedahan. Tindakan pembedahan merupakan terapi paling efektif dalam menangani kasus othematoma dengan meminimalkan tingkat kekambuhan (Schiochet et al. 2010). Tulisan ini melaporkan penanganan kasus othematoma pada kucing Persia.

\section{- KASUS}

Anamnesa, sinyalemen, dan kondisi: Kucing betina ras Persia yang belum disteril bernama Cimut berusia 3 tahun mengalami pembengkakkan pada telinga sebelah kiri (Gambar 1A). Saat dipalpasi telinga yang bengkak terasa hangat dan terisi seperti cairan. Pemeriksaan fisik: Cimut memiliki bobot badan $3,99 \mathrm{~kg}$ dan suhu tubuh $39,2{ }^{\circ} \mathrm{C}$ dengan warna membran mukosa rose, kedua telinga kotor, dan sering menggelengkan kepala. Temuan klinis: Cimut sempat mengeluarkan discharge nassal bewarna putih keruh. Pemeriksaan penunjang: Pemeriksaan serumen telinga dengan membuat preparat natif ditemukan parasit telinga Otodectes cyanotis (Gambar 1B). Hematologi lengkap menunjukkan jumlah sel darah putih, limfosit, neutrofil dan platelet tinggi (Tabel 1). Diagnosa: Othematoma sinistra. Prognosa: Fausta. Terapi: Bedah.

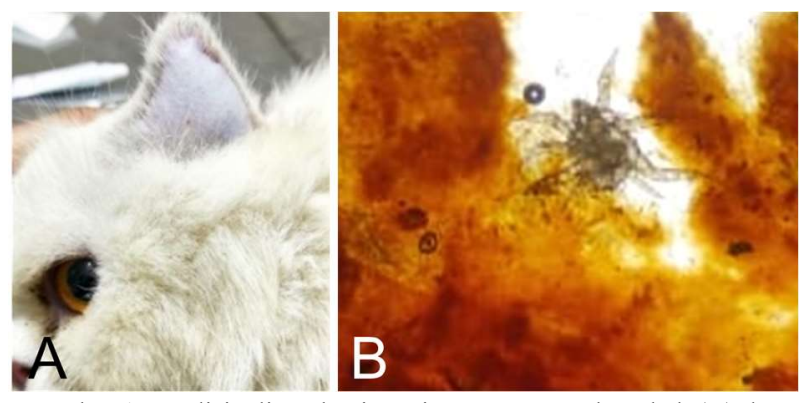

Gambar 1 Kondisi telinga kucing Cimut yang membengkak (A) dan Otodectes cyanotis pada hasil pemeriksaan serumen telinga (B).

\section{- HASIL DAN PEMBAHASAN}

Telinga Cimut terlihat adanya kebengkakkan pada daun telinga yang dikonfirmasi dengan anamnesa pemilik. Diagnosa othematoma didasarkan pada pemeriksaan klinis dan rekaman medis hewan (Silva et al. (2018). Kejadian othematoma pada kucing sebesar $76 \%$ berkaitan dengan Otodectes cyanotis (Kuwahara 1986). Informasi dari pemilik bahwa Cimut sering menggaruk telinga dan menggelengkan kepala.

Diterima: 07-03-2021 | Direvisi: 30-04-2021 | Disetujui: 02-05-2021 (C) 2021 CC-BY-SA. Ini adalah artikel Open Access yang didistribusikan berdasarkan ketentuan dari Creative Commons Attribution ShareAlike 4.0 International License (https://creativecommons.org/licenses/by-sa/4.0/) 
Hasil pemeriksaan serumen telinga ditemukan Otodectes $c y$ anotis (Gambar 1B). Pemeriksaan otoskopik pada hewan terduga othematoma untuk melihat tanda radang di dalam telinga (Sudisma 2006). Pemeriksaan telinga Cimut tidak ada peradangan. Kasus othematoma pada kucing hanya 50\% disertai otitis (Hewitt \& Bajwa 2020). Othematoma pada Cimut diduga akibat gatal dari kehadiran Otodectes cyanotis merangsang garukan dan gerakan kepala berlebihan. Gerakan menggaruk secara intens dan terus-menerus merupakan salah satu penyebab pembuluh darah di telinga pecah (Brown 2010, Irhas et al. 2019).

Tabel 1. Hematologi kucing Cimut sebelum pembedahan

\begin{tabular}{|lcc|}
\hline Parameter & Nilai pemeriksaan & Rentang normal \\
\hline Sel darah putih $\left(10^{9} / \mathrm{L}\right)$ & $\mathbf{3 6 , 3}$ & $5,5-19.5$ \\
Limfosit $\left(10^{9} / \mathrm{L}\right)$ & $\mathbf{2 4 , 3}$ & $1,5-7,0$ \\
Monosit $\left(10^{9} / \mathrm{L}\right)$ & 1,4 & $0-1,5$ \\
Neutrofil $\left(10^{9} / \mathrm{L}\right)$ & $\mathbf{1 0 , 6}$ & $2,5-1,4$ \\
Eosinofil $\left(10^{9} / \mathrm{L}\right)$ & 0,16 & $0-1$ \\
Basofil $\left(10^{9} / \mathrm{L}\right)$ & 0,12 & $0,0-0,2$ \\
Sel darah merah $\left(10^{12} / \mathrm{L}\right)$ & 7,55 & $5-10$ \\
Hemoglobin $(\mathrm{g} / \mathrm{dL})$ & 6,4 & $8-15$ \\
Hematokrit $(\%)$ & 32,6 & $24-45$ \\
MCV $(\mathrm{fl})$ & 43,3 & $39-55$ \\
MCH $(\mathrm{pg})$ & 16,8 & $12,5-17,5$ \\
MCHC $(\mathrm{g} / \mathrm{dL})$ & 38,9 & $30-36$ \\
Platelet $\left(10^{9} / \mathrm{L}\right)$ & $\mathbf{9 2 9}$ & $300-800$ \\
\hline
\end{tabular}

Keterangan: $\mathrm{MCV}=$ mean corpuscular volume, $\mathrm{MCH}=$ mean corpuscular hemoglobin, $\mathrm{MCHC}=$ mean corpuscular hemoglobin concentration .

Penanganan dengan tindakan bedah dipilih karena efektif tingkat kesembuhan dengan tingkat kekambuhan yang rendah. Othematoma umumnya mudah ditangani bila belum menjadi tumor, darah mudah mengalir saat ditusuk dengan jarum (Harvey et al. 2005). Beberapa kasus sudah dilakukan dengan centesis yang diikuti injeksi obat untuk mengurangi pembengkakan dan peradangan. Namun, sebagian besar hematoma kembali muncul kembali (Llera 2021).

Tindakan bedah untuk menangani othematoma pada Cimut (Gambar 2). Bedah dilakukan dengan anastesi general menggunakan premedikasi atropin sulfat $(0,1 \mathrm{ml} / \mathrm{kg})$ subkutan dan induksi kombinasi zoetil $(0,05 \mathrm{ml} / \mathrm{kg})$-xylazin $(0,1$ $\mathrm{ml} / \mathrm{kg}$ ) intramuskular. Sayatan linier di tengah daun telinga yang bengkak pada sisi dalam (Gambar 2A). Hematoma dikeluarkan dan deposit fibrin pada tulang rawan dikuratori (Gambar 2B). Penjahitan simple interrupted suture mengelilingi sayatan menggunakan silk 3.0 (Gambar 2C).

Luka sayatan dibiarkan terbuka agar sisa hematoma keluar. Luka diolesi salep Biogenta (Bioplacenton dan gentamicin) untuk mempercepat penyembuhan luka dan menghindari infeksi pascabedah. Penutupan telinga dengan balut tekan (Gambar 2D). Cimut dipakaikan Elizabeth collar untuk menghindari garukkan yang dapat merusak jahitan. Pengobatan post operatif diberikan antibiotik amoxycillin 0,1 $\mathrm{ml} / \mathrm{kg} \mathrm{sc}$, Tolfedin ${ }^{\circledR} 0,05 \mathrm{ml} / \mathrm{kg}$ im, vitamin penambah napsu makan $0,1 \mathrm{ml} / \mathrm{kg}$ dan immunomodulator $0,5 \mathrm{ml} / \mathrm{kg}$ per oral, dan anti-fibrinolitik asam traneksamat $0,1 \mathrm{ml} / \mathrm{kg}$ iv untuk menghentikan pendarahan pascabedah. Menurut MacPhail (2016), balut tekan dilakukan minimal 3 minggu sampai luka terlihat kering dan mulai membentuk jaringan baru.

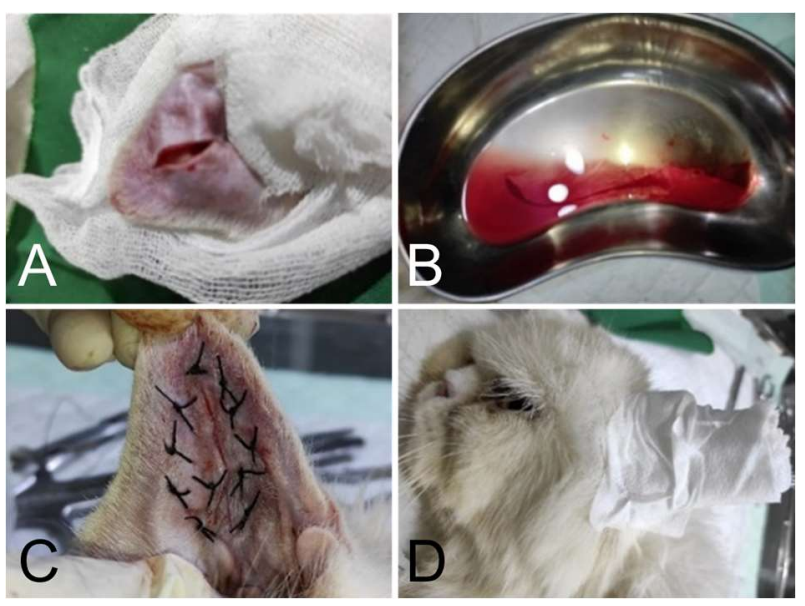

Gambar 2 Prosedur pembedahan telinga kucing Cimut. (A) sayatan pada daun telinga, (B) hematoma, (C) penjahitan daun telingan, dan (D) balut tekan pada daun telinga.

\section{SIMPULAN}

Tindakan bedah merupakan penanganan yang efektif pada kasus othematoma pada kucing.

\section{- INFORMASI PENULIS}

\section{Penulis Korespondensi}

*ARN: ananasheer97@gmail.com

Mahasiswa Program Pendidikan Profesi Dokter Hewan, Fakultas Kedokteran Hewan, Institut Pertanian Bogor, Jln Agatis Kampus IPB Dramaga, Bogor, Jawa Barat, Indonesia

\section{- PUSTAKA ACUAN}

Brown C. 2010. Surgical management of canine aural hematoma. Lab Animal. 39(4): 104-105.

Harvey RG, Harari J, Delauche AJ. 2005. Ear Diseases of The Dog and Cat. Spokane (USA): Manson Publishing. p226-231.

Henderson RA, Horne R. Pinna. In: Slatter D, ed Textbook of Small Animal Surgery. 3rd ed. Philadelphia, Pa: Saunders, 2003;1737-1741.

Hewitt J, Bajwa J. 2020. Aural hematoma and it's treatment: a review. The Canadian Veterinary Journal. 61(3): 1-3.

Irhas R, Jayawardhita AAG, Dada IKA. 2019. Studi kasus: aural hematoma pada anjing local berumur 12 tahun. Indonesia Medicus Veterinus. 8(6): 719-727.

Islami DN, Dewi CMS, Triana NM, Purnama MTE. 2018. Laporan kasus: otitis eksterna dan auricular hematoma (othematom) pada anjing Samoyed. Jurnal Medik Veteriner. 1(3): 80-86.

Kuwahara J. 1986. Canine and feline aural hematomas: clinical experimental, and clinicopathological observations. American Journal of Veterinary Research. 47: 2300-2308.

Llera R. 2021. Hematoma of the ear in cats. VCA Hospitals [Internet]. [Diunduh pada: 2021 Januari 23]. Tersedia pada: https://vcahospitals.com/know-your-pet/hematoma-of-the-ear-in-cats

MacPhail C. 2016. Current treatment options for auricular hematomas. Vet Clin North Am Small Anim Pract. 46(4):635-641

Schiochet F, Teixeira E, Rodrigues PRC, Gimosk AW, Beck CA Contesini EA, Alievi MM, Fratini LM. 2010. Aural hematoma in cat: case report. Veterinaria Em Foco. 7(2): 198-205.

Silva RA, Rodrigues KF, Santos TGR, Sampaio TB, Sousa PMV, Silva KM, Silva TS. 2018. Hematoma aural em gato jovem: relato de caso. Medicina Veterinaria E-Zootecnia. 12(2): 1-4.

Sudisma N, dkk. 2006. Ilmu Bedah Veteriner dan Teknik Operasi. Denpasar (ID): Universitas Udayana. 